\title{
Uncertainties of stormwater characteristics and removal rates of stormwater treatment facilities: Implications for stormwater handling
}

\author{
J.G. Langeveld ${ }^{a, b, *}$, H.J. Liefting ${ }^{b}$, F.C. Boogaard ${ }^{a}$ \\ ${ }^{a}$ Department of Sanitary Engineering, Faculty of Civil Engineering and Geosciences, Delft University of Technology, P.O. Box 5048, \\ NL-2600 GA Delft, The Netherlands \\ ${ }^{\mathrm{b}}$ Royal Haskoning, Barbarossastraat 35, P.O. Box 151, 6500 AD Nijmegen, The Netherlands
}

\section{A R T I C L E I N F O}

\section{Article history:}

Received 30 June 2011

Received in revised form

24 May 2012

Accepted 1 June 2012

Available online 15 June 2012

Keywords:

Monitoring

Uncertainty

Stormwater treatment

Stormwater characteristics

Event mean concentration

Site mean concentration

Lamella settler

Soil filter

Sand filter

\begin{abstract}
A B S T R A C T
Stormwater runoff is a major contributor to the pollution of receiving waters. This study focuses at characterising stormwater in order to be able to determine the impact of stormwater on receiving waters and to be able to select the most appropriate stormwater handling strategy. The stormwater characterisation is based on determining site mean concentrations (SMCs) and their uncertainties as well as the treatability of stormwater by monitoring specific pollutants concentration levels (TSS, COD, BOD, TKN, TP, Pb, Cu, Zn, E.coli) at three full scale stormwater treatment facilities in Arnhem, the Netherlands. This has resulted in 106 storm events being monitored at the lamella settler, 59 at the high rate sand filter and 132 at the soil filter during the 2 year monitoring period.

The stormwater characteristics in Arnhem in terms of SMCs for main pollutants TSS and COD and settling velocities differ from international data. This implies that decisions for stormwater handling made on international literature data will very likely be wrong due to assuming too high concentrations of pollutants and misjudgement of the treatability of stormwater. The removal rates monitored at the full scale treatment facilities are within the expected range, with the soil filter and the sand filter having higher removal rates than the lamella settler. The full scale pilots revealed the importance of incorporating gross solids removal in the design of stormwater treatment facilities, as the gross solids determine operation and maintenance requirements.
\end{abstract}

(c) 2012 Elsevier Ltd. All rights reserved.

\section{Introduction}

Separate sewer systems are widely applied in economically developed countries. Storm sewers are known to contribute significantly to the annual pollutant loads into the receiving waters and to cause severe degradation of urban receiving waters (House et al., 1993). In the United States, stormwater runoff is the major contributor to pollution of receiving waters (Lee et al., 2007). The European Water Framework Directive (WFD) (2000/60/EC, 23 October 2000) aims at achieving a good status for all European water bodies. In order to be able to comply with the WFD, local water authorities in member states have to develop stormwater management strategies able to enhance local receiving water quality to the desired

\footnotetext{
${ }^{*}$ Corresponding author. Department of Sanitary Engineering, Faculty of Civil Engineering and Geosciences, Delft University of Technology, P.O. Box 5048, NL-2600 GA Delft, The Netherlands. Tel.: +31 622409565.

E-mail address: j.g.langeveld@tudelft.nl (J.G. Langeveld).

0043-1354/\$ - see front matter (c) 2012 Elsevier Ltd. All rights reserved.

http://dx.doi.org/10.1016/j.watres.2012.06.001
}

End of preview. The entire article is 13 pages. 